\title{
Community-based interventions to support maternal and child health practices in Upper Egypt
}

\author{
Laila Kamel, ${ }^{1}$ Shaimaa Abdel-Aziz ${ }^{1}$ and Hanaa Zaghloul Yousof ${ }^{1}$ \\ 롤 \\ kasralainy.edu.eg).
}

\begin{abstract}
Background: Actions to improve mother and child health should address the needs and demands of the local population. Community-based interventions contribute to understanding the current situation, mobilization of local resources, commitment to achievements and better chance for sustainability.

Aims: This was a community-based intervention implemented in two Upper Egypt governorates to improve coverage of selected maternal and child health interventions in Egyptian villages.

Methods: The study was conducted between May 2016 and December 2017. The National Population Council started communication with Governorate leaders, Directors of Local Unit, Health District and Health Unit to facilitate implementation. A three-day training of trainers workshop was held for eight public health universities' staff from two selected governorates. More than 30 National Population Council coordinators were trained for using an observation checklist. University trainers implemented a four-day workshop attended by 37 Mother and Child Friends participants from Fayoum and 38 from Beni-Sweif. The Mother and Child Friends team selected 1200 women to attend the Health education sessions, and a total of 143 and 121 women participated in the focus group discussions before the first and after the last Health education session for evaluation.

Results: An 18 items pre-test questionnaire completed by the trainees was useful to identify major gaps in knowledge and to evaluate the effect of training. There was significant improvement in the post-test in Fayoum (15.6 \pm 1.3 SD) and

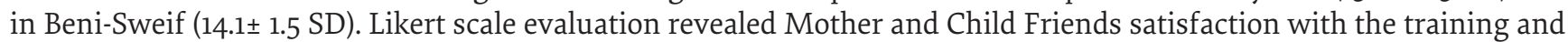
Mother and Child Friends team provided Health education to the participants. Most of the sessions had no negative comments by the observers. Focus group discussions held after the Health education classes revealed positive changes in the participants' knowledge and attitude.

Conclusions: Implementation revealed that more needs were expressed by women and the Mother and Child Friends team. Future activities should consider customization to address community needs and expectations.

Keywords: Community-based interventions, maternal health, child health, health education, Egypt

Citation: Kamel L; Abdel-Aziz S; Yousof H. Community-based interventions to support maternal and child health practices in Upper Egypt. East Mediterr Health J. 2019;25 (9):597-603. https://doi.org/10.26719/emhj.18.069

Received: 26/05/18; accepted: 30/10/18

Copyright (C) World Health Organization (WHO) 2019. Some rights reserved. This work is available under the CC BY-NC-SA 3.0 IGO license (https:// creativecommons.org/licenses/by-nc-sa/3.o/igo).
\end{abstract}

\section{Introduction}

The Egyptian government is paying great attention to the achievement of the Sustainable Development Goals, as expressed in the document "Strategy for Sustainable Development - Egypt Vision 2030" (1). The National Population Strategy 2015-2030 (2) addressed maternal health, child health and family planning; both documents identified strategies and defined the national indicators used. The National Population Council realized the need for disaggregated data and identified more than 70 indicators and developed "composite indicators" at the level of the governorates and districts, which were classified into three levels: green zone for best indicators, yellow zone for moderate, and red zone for the worst (3).

To be effective, national strategies should be translated into actions that reach communities, families and individuals at the grass root level. Egypt is covered by a network of 5314 primary health care facilities (4) and almost half of them are implementing the "Family Health Model". Health education is a core component for care provided by primary health care centres. The availability of primary health care facilities have contributed to the trend of gradual improvement of health indicators, as shown by the results of the successive Egyptian Demographic and Health Surveys conducted since 1988, the latest being in 2014 (5). However, a WHO report stated that, "Available data indicate that despite the progress made during the MDG era major challenges remain in terms of reducing maternal and child mortality, and improving nutrition" (6).

This study conducted a trial to create a model to support healthy practices to improve health and nutrition of women and children aged under five years in Egyptian rural settings through implementing community-based interventions.

\section{Methods}

\section{Setting and sample}

This is an intervention study based on community involvement with support obtained at the governorate level. 
Selected and trained teams of local young females identified as "Mother and Child Friends" provided health education to women. Local universities were involved in the process of training the Mother and Child Friends team.

Two Upper Egypt Governorates, Fayoum and BeniSweif, were purposefully selected to fulfill certain criteria: moderate level (yellow zone) according to composite indicators (3), have a medical school, and be accessible to National Population Council staff. One yellow zone district was selected in each governorate (Sennoris in Fayoum and Beni-Sweif in Beni-Sweif) and one easily accessible village purposefully selected from each district. An important criterion is a reasonably functioning health unit able to respond to the potential increased demand on service. The two villages selected were Behmo in Fayoum and Belvia in Beni-Sweif.

The strategy was to identify priority health messages to be communicated to a target group of women of childbearing age. The messages addressed main health / health-related problems as identified by Egyptian Demographic and Health Surveys surveys (6) and as recommended by "Facts for Life" prepared by UNICEF (7). An Egyptian Mother Guide: "Proper practices for health of the mother and child" was prepared in a simple language, which included advice on healthy life style, marriage, care for the pregnant mother, nutrition during pregnancy, alarming signs in pregnancy, preparation for delivery, delivery and purperium, postpartum alarming signs, alarming signs for the neonate, family planning, proper nutrition, breast feeding, weaning, child health, promotion of child development, diarrhoea and acute respiratory infection. These messages formed the basis for training the Mother and Child Friends team. A copy of the guide was delivered to every woman attending health education classes.

\section{Implementation of the study}

The study was implemented over a period of 18 months starting May 2016 and included the following:

- Contacting public health departments in Fayoum and Beni-Sweif universities to nominate staff to participate as trainers for the Mother and Child Friends group. Four lecturer public health staff members were nominated from each university.

- Preparation of a training manual for university staff, introducing objectives and process of implementation of the intervention, principles of effective training for trainers, and the manual for the Mother and Child Friends group.

- The research team held a three-day training of trainers workshop for universities' staff at National Population Council premises. National Population Council staff and junior staff attended the workshop from PHD, Cairo University. First day was orientation about project activities, principles of training of trainers, basic communication skills, and explanation of "role playing". Each participant was assigned a topic to present on the following day. On the last day, par- ticipants prepared their agenda for governorate training and completed a seven question evaluation sheet. Each question set a score of 10. The same evaluation sheet was completed after implementing Mother and Child Friends training.

- A one-day orientation workshop was held for more than 30 National Population Council staff to train them on observing the Mother and Child Friends training and the women Health education sessions using structured observation checklists.

- The governor and governorate leaders attended an orientation meeting held at governorate headquarters, including the vice-minister for population, National Population Council rapporteur, National Population Council key project staff and National Population Council governorate office representatives.

- A meeting held at the local village unit was facilitated by researchers and the National Population Council project team and attended by directors of the local unit, health district, health unit and community developmentassociation, religiousleaders, schooldirectors, teachers and community leaders. The meeting was intended for orientation and initiation of community involvement. Participants discussed criteria for selection of Mother and Child Friends team and target women, defining places to implement Mother and Child Friends training and delivering women Health education classes.

- The director of the local unit and group was asked to select the Mother and Child Friends team. Criteria for selection included: female, aged 18 years or more, completed secondary education or more, and having an agreeable personality.

- University trainers implemented a four-day workshop that was attended by 37 Mother and Child Friends participants from Fayoum and 38 from Beni-Sweif. Training covered communication skills and Health education messages. On the fourth day selected participants were asked to deliver Health education messages and receive comments from trainers and their colleagues. National Population Council staff observed the training sessions. Mother and Child Friends who could implement mothers' Health education classes were identified. A total of 16 educators were selected in Fayoum and 24 in Beni-Sweif. Trainees completed pre- and post-tests, and Likert scale evaluation sheets. National Population Council observers using a structured checklist assessed the quality.

- The selected Mother and Child Friends team was instructed to select women to attend Health education sessions. Six hundred women were purposefully selected from each village. Women aged 18-50 years were recruited from different parts of the village so messages received would be disseminated through the whole village.

- Women from each village were divided into 24 groups containing 25 participants. Each woman attended 
three one-day sessions over a period of three weeks and received the "Egyptian Mother Guide". Classes were facilitated by two trained Mother and Child Friends. Public health staff and trained National Population Council coordinators observed the sessions.

- Focus group discussions for evaluation of Health education before the first and after last session took place. A total of 143 and 121 women participated in focus group discussions in both villages with an average of 10-12 women per focus group. Trained Cairo University staff conducted focus group discussions and a focus group discussion guide was prepared to keep discussions on track and facilitate data analysis $(8,9)$.

\section{Ethical consideration}

Approval was obtained from the vice-minister for population, National Population Council rapporteur, and UNICEF. At the local level, the governors and directors approved the study. Informed consent was obtained from each participant after explanation of the objectives. Those not willing to participate could withdraw any time. We assured confidentiality and privacy throughout the study period.

\section{Data management and statistical analysis}

Data were entered and analyzed using SPSS. Pre/posttest score was 1 for the right answer, while wrong or 'don't know' was zero. Mean, SD and t-test were used for comparison. $P$ value less than 0.05 was considered statistically significant. Analysis and coding of the focus group discussion was done at the village level $(8,9)$.

\section{Results}

Eight lecturers attended the training of trainers workshop from the public health departments at Fayoum and Beni-Sweif universities. Immediate evaluation scores were 90\%; after implementing Mother and Child Friends training, they re-scored at $98 \%$. Public health departments staff expressed their interest in expansion of similar activities in other villages and recommended more Health education material and more days of training. They also suggested expanding the group of Mother and Child Friends educators to include secondary school female students.

Sociodemographic characteristics of the Mother and Child Friends trainees fulfilled the pre-set criteria for selection (Table 1). An 18 item pre-test questionnaire was completed by the trainees was useful to identify major gaps in knowledge and to evaluate the effect of training (Table 2). There was significant improvement in Fayoum $(10.6+3.4$ in pre-test and $15.6 \pm 1.3$ in post-test $)$ and in Beni-Sweif $(11.2+2.2$ in pre-test and $14.1 \pm 1.5$ in posttest). On average, there was a statistically significant improvement in the post-test, although the knowledge score was not highly satisfactory in either $(P<0.001)$.

Using Likert scale evaluation revealed Mother and Child Friends satisfaction with the training; only two in Beni-Sweif were not sure they could provide

\begin{tabular}{|c|c|c|c|c|}
\hline Characteristics & \multicolumn{2}{|c|}{$\begin{array}{c}\text { Fayoum } \\
\mathrm{N}=37(100 \%)\end{array}$} & \multicolumn{2}{|c|}{$\begin{array}{l}\text { Beni-Sweif } \\
\mathrm{N}=38(\mathbf{1 0 0} \%)\end{array}$} \\
\hline \multicolumn{5}{|l|}{ Age in years } \\
\hline $\begin{array}{l}\text { Mean }(+S D) \\
\text { Min - maximum }\end{array}$ & \multicolumn{2}{|c|}{$\begin{array}{l}22.9 \pm 2.3 \\
19-28\end{array}$} & \multicolumn{2}{|c|}{$\begin{array}{c}24.0 \pm 3.2 \\
19-30\end{array}$} \\
\hline Education & $\mathrm{N}$ & $\%$ & $\mathrm{~N}$ & $\%$ \\
\hline $\begin{array}{l}\text { Middle / secondary education } \\
\text { High education }\end{array}$ & $\begin{array}{l}25 \\
12\end{array}$ & $\begin{array}{l}67.6 \\
32.4\end{array}$ & $\begin{array}{l}22 \\
16\end{array}$ & $\begin{array}{l}57.9 \\
42.1\end{array}$ \\
\hline \multicolumn{5}{|l|}{ Work status } \\
\hline $\begin{array}{l}\text { Yes } \\
\text { No }\end{array}$ & $\begin{array}{l}14 \\
23\end{array}$ & $\begin{array}{l}37.8 \\
62.2\end{array}$ & $\begin{array}{l}12 \\
26\end{array}$ & $\begin{array}{l}31.6 \\
68.4\end{array}$ \\
\hline \multicolumn{5}{|l|}{ Marital status } \\
\hline $\begin{array}{l}\text { Single } \\
\text { Married } \\
\text { Divorced }\end{array}$ & $\begin{array}{c}8 \\
25 \\
4\end{array}$ & $\begin{array}{l}21.6 \\
67.6 \\
10.8\end{array}$ & $\begin{array}{c}14 \\
22 \\
2\end{array}$ & $\begin{array}{c}36.8 \\
57.9 \\
5.3\end{array}$ \\
\hline
\end{tabular}

Health education. The most useful topics from the Mother and Child Friends point of view differed between the two villages; in Fayoum consanguinity, premarital examination, proper nutrition, early marriage and breast-feeding, while in Beni-Sweif delivery and postpartum care, premarital examination, early marriage and postpartum dangerous signs were considered priority.

The Mother and Child Friends team provided Health education to the participants. Observations done by the public health trainers and National Population Council coordinators revealed the participants gave good dedication to time (94\%) and all Mother and Child Friends groups attended on time. National Population Council coordinators reported positive comments, sessions were interactive and the performance of the educators was good. The women were glad to receive the Egyptian Mother Guide and they were satisfied with place and time, and by educators' responses. Most of the sessions had no negative comments by the observers.

Focus group discussions conducted before educational sessions revealed the women had a reasonable knowledge in relation to their health and the health of their newborns, and showed good intentions to improve. (Table 3). Focus Group discussions held after the Health education classes revealed positive changes in women's knowledge and attitude, although they had some concerns about their economic ability to have adequate diet in view of the rising prices of food. The most important knowledge gained from the Health education classes is presented in Table 4.

The women had some concerns and asked to know more about controversial issues such as female genital mutilation, early childhood development and adolescent health. Interaction with women pointed to an expected increase in service utilization, and the women and the Mother and Child Friends team mentioned the need for service improvement. 


\begin{tabular}{|c|c|c|c|c|c|c|c|c|}
\hline \multirow[t]{3}{*}{ Questionnaire items } & \multicolumn{4}{|c|}{ Correct answers- Fayoum group } & \multicolumn{4}{|c|}{ Correct answers - Beni-Sweif group } \\
\hline & \multicolumn{2}{|c|}{ Pre-test } & \multicolumn{2}{|c|}{ Post-test } & \multicolumn{2}{|c|}{ Pre-test } & \multicolumn{2}{|c|}{ Post-test } \\
\hline & $\mathrm{N}=37$ & $\%$ & $\mathrm{~N}=33$ & $\%$ & $\mathrm{~N}=38$ & $\%$ & $\mathrm{~N}=38$ & $\%$ \\
\hline 1. Importance of pre-marital examination & 29 & 78.4 & 32 & 97.0 & 36 & 94.7 & 36 & 94.7 \\
\hline 2. Appropriate age for marriage & 36 & 97.3 & 32 & 97.0 & 38 & 100 & 38 & 100 \\
\hline 3. Number of ANC visits & 4 & 10.8 & 32 & 97.0 & 7 & 18.4 & 34 & 89.5 \\
\hline 4. High-risk pregnancy & 17 & 45.9 & 9 & 27.3 & 14 & 36.8 & 18 & 47.4 \\
\hline 5. Proper nutrition during pregnancy & 31 & 83.8 & 30 & 90.9 & 27 & 71.1 & 35 & 92.1 \\
\hline 6. Post-natal maternal complications & 31 & 83.8 & 32 & 97.0 & 36 & 94.7 & 37 & 97.4 \\
\hline 7. Post-natal and neonatal complications & 33 & 89.2 & 33 & 100 & 35 & 94.7 & 38 & 100 \\
\hline 8. Maternal post-natal care & 18 & 48.6 & 31 & 93.9 & 22 & 57.9 & 37 & $97 \cdot 4$ \\
\hline 9. Breast feeding & 16 & 43.2 & 26 & 93.9 & 26 & 68.4 & 36 & 94.7 \\
\hline 10. Family planning contraceptive methods & 21 & 58.3 & 29 & 87.9 & 11 & 28.9 & 3 & 7.9 \\
\hline 11. Proper inter-pregnancy spacing & 17 & 47.2 & 29 & 87.9 & 5 & 13.2 & 21 & $55 \cdot 3$ \\
\hline 12. Neonatal post-natal care & 27 & 73 & 29 & 87.9 & 25 & 65.8 & 38 & 100 \\
\hline 13. Pregnancy-associated disorders & 9 & 24.3 & 21 & 63.6 & 12 & 65.8 & 27 & 71.1 \\
\hline 14. Immunization & 31 & 83.9 & 33 & 100 & 34 & 89.5 & 37 & 97.4 \\
\hline 15. Well baby care & 18 & 48.6 & 28 & 84.8 & 24 & 63.2 & 30 & 78.9 \\
\hline 16. Management of diarrhoeal diseases & 17 & 45.9 & 28 & 84.8 & 18 & 47.4 & 28 & 73.7 \\
\hline 17. Sick baby care & 17 & 45.9 & 27 & 81.8 & 27 & 71.1 & 32 & 84.2 \\
\hline 18. Proper nutrition and healthy life style & 19 & 51.4 & 33 & 100 & 14 & 36.8 & 26 & 68.4 \\
\hline Achieved mean knowledge score $( \pm S D)$ & \multicolumn{2}{|c|}{$10.6( \pm 3.4)$} & \multicolumn{2}{|c|}{$15.6( \pm 1.3)$} & \multicolumn{2}{|c|}{$11.2( \pm 2.2)$} & \multicolumn{2}{|c|}{$14.1( \pm 1.5)$} \\
\hline Pvalue & \multicolumn{4}{|c|}{0.001} & \multicolumn{4}{|c|}{0.001} \\
\hline
\end{tabular}

\begin{tabular}{|c|c|}
\hline Theme & Finding \\
\hline Age of marriage & $\begin{array}{l}\text { Many girls marry before } 18 \text { years, } 14-15 \text { years is very common. They are aware of the health and } \\
\text { legal problems and problems to register births without a legal marriage certificate; however, it is a } \\
\text { social norm. Six of the attendants married before } 18 \text { years of age. }\end{array}$ \\
\hline \multirow[t]{3}{*}{ Premarital examination and counseling } & $\begin{array}{l}\text { Women are aware that premarital examination is required to register the marriage officially; } \\
\text { however, it is not available. }\end{array}$ \\
\hline & They pay money and get the required permission to register their marriage. \\
\hline & Only seven women mentioned they had check-ups. \\
\hline Consanguineous marriage & $\begin{array}{l}\text { Consanguineous marriage is common as it is a social norm; e.g., "Because he is my relative, I know } \\
\text { him", "I wish my son married one of his relatives, she will be kind and lovely". }\end{array}$ \\
\hline Deliveries & $\begin{array}{l}\text { Deliveries take place at hospital; home deliveries are very rare. Women said physicians prefer to do } \\
\text { a caesarian delivery "because they earn more money". Women do not want to experience the pain } \\
\text { of delivery or the sutures of episiotomy routinely performed with vaginal delivery. }\end{array}$ \\
\hline \multirow[t]{3}{*}{ Governmental health services } & $\begin{array}{l}\text { Women were not satisfied by the governmental health services. "The quality of service is poor", } \\
\text { "The physician is not regularly available", "limited resources and drugs". }\end{array}$ \\
\hline & Women usually go to private physicians. \\
\hline & $\begin{array}{l}\text { They go to the unit for tetanus vaccinations and to have some check-ups and vitamins during } \\
\text { pregnancy. }\end{array}$ \\
\hline
\end{tabular}

\section{Discussion}

The Global Strategy for Women's, Children's and Adolescents' Health (2016-2030) "strives for a world in which every mother can enjoy a wanted and healthy pregnancy and childbirth. Every child can survive beyond their fifth birthday, and every woman, child and adolescent can thrive to realize their full potential, resulting in enormous social, demographic and economic benefits" (10). This study conducted trialed a model for implementing replicable interventions to improve health and nutrition of women and children aged under five years in Egyptian rural settings. The model demonstrated links between 


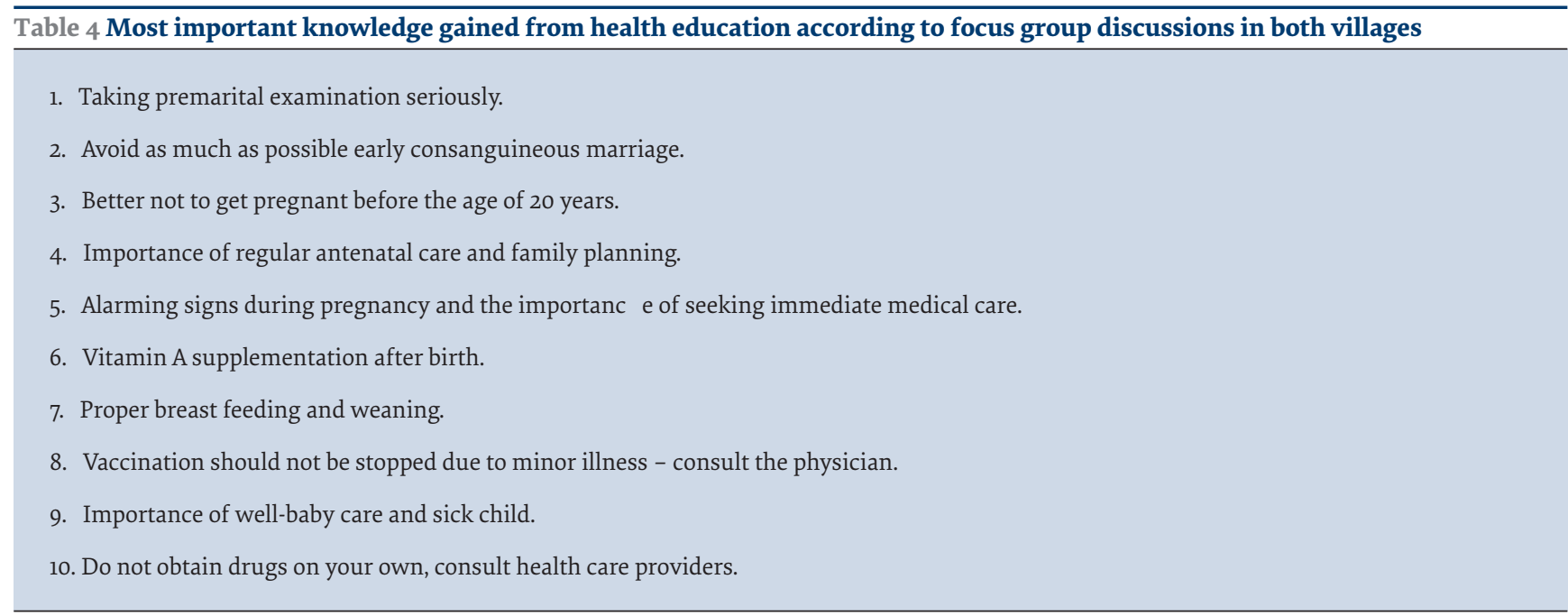

different levels, starting from National Population Council, governorate universities and local communities.

Senior and middle level staff was satisfied by their contribution. This is a "learning by doing" exercise. The capacity building for National Population Council staff would be a building block for similar activities in other areas. Universities are important focal points in leading community development activities. What is needed is real community involvement through university-community engagement and/or partnership (11). In the current study, public health departments in either governorate were engaged from the very beginning. The interest shown and knowledge gained is an excellent potential for sustainability and replication.

It is widely agreed that communities should take an active part in improving their own health outcomes. (12). Community-based initiatives are an integrated bottomup approach to socioeconomic development, including health, aiming at achieving better quality of life for communities. A community-based initiatives programme was introduced in Egypt in 1999 with the support of the World Health Organization Regional Office for the Eastern Mediterranean (WHO/EMRO) (13). Community involvement would better address their demands and create a sense of ownership and responsibility to support sustainability. In the present study, MSF, which is part of the community, targeted women and spelled out specific topics needed and which should be considered with further education for community members. The local university staff could support customization of interventions.
Interaction with the community should consider critical health literacy, respond to local situations and support community, consider determinants of health and exert greater control on people's health and wellbeing (14). Interaction with MSF and with women during health education classes and focus group discussions revealed different factors related to culture or social norms that need to be addressed.

An important issue is the high rate of caesarean section deliveries. This has been of great concern to community leaders who participated in the initial meetings. Egyptian Demographic and Health Surveys 2014 reported a 51.8\% caesarean section rate, which is very high. Caesarean section was addressed in the Health education messages to women; however, the message has to be customized to the local situation. Women should learn how to prepare their "birth plan" with their physician, to inform them they are not going to have a caesarean section or episiotomy unless necessary. In Egypt, episiotomy is almost routine in vaginal deliveries. In 2006, the American Congress of Obstetricians and Gynaecologists recommended "restricted use" of episiotomy (15). Such issues could not be addressed by health education alone; it should be addressed by the health system and included in medical education. In conclusion, this study demonstrated the importance of community involvement and role of university-community engagement to address local needs and improve health and quality of life in neighboring communities.

\section{Acknowledgments}

We thank all the Mother and Child Friends groups and participants in this study for their commitment in responding to the interviews. We also thank Prof. Maissa Shawky (Vice-Minister for Population), Prof. Tarek Tawifk (National Population Council Rapporteur) for guidance and support, National Population Council key project staff Sameer Abo Raya (General Administration of population plans National Population Council), and Sahar Youssef (Director of the Planning department at the sub-national level).

Funding: UNICEF.

Competing interests: None declared. 


\section{Interventions communautaires à l'appui des pratiques en matière de santé de la mère et de l'enfant en Haute Égypte}

\section{Résumé}

Contexte : Les mesures visant à améliorer la santé de la mère et de l'enfant doivent répondre aux besoins et à la demande de la population locale. Les interventions communautaires permettent de comprendre la situation présente, de mobiliser les ressources locales et de s'engager en faveur de réalisations. Enfin elles ont plus de chances d'être pérennes.

Objectifs : Il s'agit d'une intervention communautaire mise en œuvre dans deux gouvernorats de Haute Égypte afin d'améliorer la couverture d'un certain nombre d'interventions concernant la santé maternelle et infantile dans des villages égyptiens.

Méthodes : La présente étude a été réalisée entre mai 2016 et décembre 2017. Le Conseil national populaire a entamé un dialogue avec les dirigeants du gouvernorat, les responsables de l'unité locale, le district et l'unité de santé afin de faciliter la mise en œuvre de l'intervention. Un atelier de trois jours consacré à la formation de formateurs a été organisé auquel ont participé huit membres du personnel des universités de santé publique des deux gouvernorats retenus. Plus de 30 coordonnateurs du Conseil national populaire ont été formés à l'utilisation d'une liste de contrôle d'observation. Des formateurs de l'université ont organisé un atelier de quatre jours auquel ont participé 37 personnes de l'ONG « Mother and Child Friends » originaires de Fayoum et 38 autres de Beni-Sweif. L'équipe de Mother and Child Friends a sélectionné 1200 femmes pour participer aux sessions d'éducation sanitaire et un total de 143 et 121 femmes ont participé aux échanges par groupes thématiques avant la première session et après la dernière pour évaluation.

Résultats : Un questionnaire préliminaire à 18 items rempli par les personnes formées a permis d'identifier des lacunes importantes en matière de connaissances et d'évaluer l'impact de la formation. Le test réalisé après la formation à Fayoum (ET 15,6 — 1,3) et à Beni-Sweif (ET 14,1 — 1,5) a montré une amélioration considérable. L'évaluation au moyen de l'échelle de Likert a montré que les membres de MCF étaient satisfaits de la formation et l'équipe de MCF a mis en place des sessions d'éducation sanitaire destinées aux participants. Globalement, les sessions n'ont donné lieu à aucun commentaire négatif de la part des observateurs. Les échanges par groupes thématiques proposés après les cours d'éducation sanitaire ont mis en lumière des changements positifs s'agissant des connaissances et de l'attitude des participantes.

Conclusions : La mise en œuvre de l'intervention a montré que les femmes et l'équipe de MCF exprimaient un plus grand nombre de besoins. Les futures activités devront être adaptées afin de prendre en compte les besoins et les attentes des communautés.

$$
\begin{aligned}
& \text { تدخلات بجتمعية لدعم ممارسات صحة الأمهات و الأطفال في صعيد مصر } \\
& \text { ليلى كامل، شياء عبد العزيز، هناء زغلول يوسف مارسفات } \\
& \text { الخلاصة }
\end{aligned}
$$

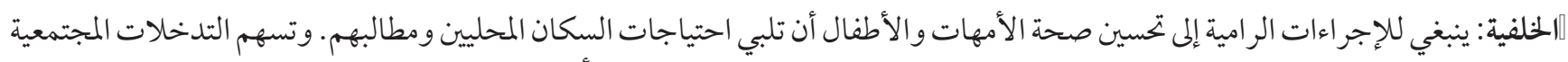

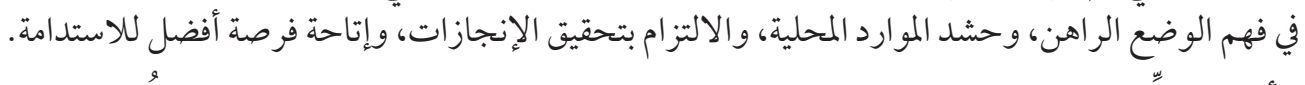

الأهداف: نفّذّ هذا التدخل المجتمعي في محافظتين في صعيد مصر لزيادة نطاق التغطية بتدخلات فُختارة تتعلق بصحة الأمهات والأطفال في القرى المصرية.

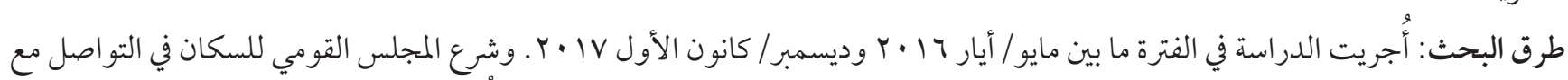

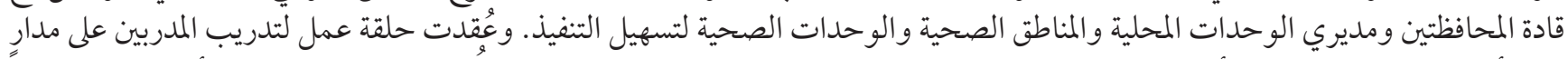

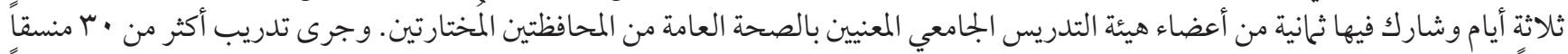

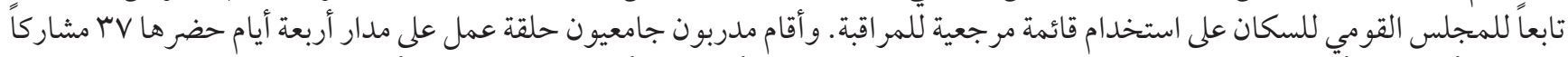

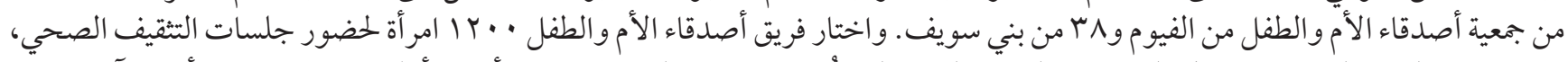

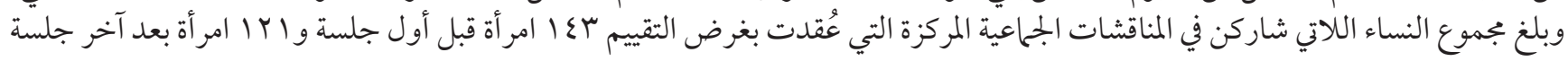
من جلسات التثقيف الصحي.

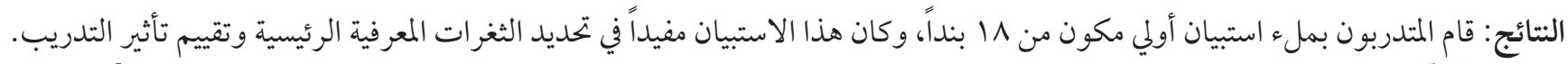

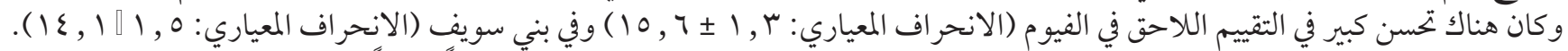

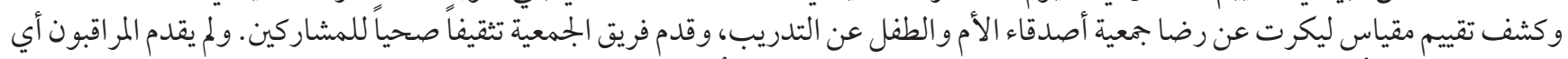

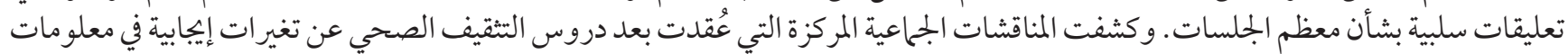
المشار كين ومو اقفهم. 
الاستنتاجات: أظهر التنفيذ أن النساء وفريق أصدقاء الأم و الطفل لديهم مزيد من الاحتياجات. وينبغي أن يُراعى تكييف الأنشطة المستقبلية لتلبية احتياجات المجتمع وتوقعاته.

\section{References}

1. Council of Ministers. Strategy for sustainable development. Egypt Vision 2030. Cairo: Ministry of Planning; 2016 (http://sdsegypt2030.com/?lang=en/).

2. Ministry of Health and Population. The national population strategy 2015-2030. Cairo: National Population Council (NPC); 2016 (http://www.npc.gov.eg/images/pdf/).

3. Ministry of Health and Population \& Egypt National Population Council. UNFPA atlas for population development, Egypt Arab Republic (Arabic). Cairo: National Population Council; 2016 (http://www.npc.gov.eg/images/pdf/).

4. Statistical year book; 2016. Egypt: Cairo: Central Agency for Public Mobilization and Statistics; 2016 (http://arabdevelopmentportal.com/publication/egypt-figures-2016-education).

5. Egypt Demographic and Health Survey 2014. Cairo: Ministry of Health and Population; 2014 (https://dhsprogram.com/pubs/pdf/ FR302/FR302.pdf).

6. Monitoring Health for the SDGs. Geneva: World Health Organization; 2017 (http://www.who.int/gho/publications/world_ health_statistics/2017/en/).

7. Facts for Life. What every Egyptian family must know for a healthy life; Cairo: Ministry Of Health and Population, UNICEF; 2014.

8. Guidelines for Conducting Focus Group Discussions. CHs Alliance (https://www.chsalliance.org/files/files/Resources/Tools-andguidance/Belfrage-and-Wigley_Guidelines-for-Focus-Group-Discussions.pdf).

9. Onwuegbuzie AJ, Dickinson WB, Leech NL, Zoran AG. A Qualitative framework for collecting and analyzing data in focus group research. Int J Qualit Methods. 2009;8(3) (http://research.apc.org/images/2/2f/A_Qualitative_Framework_for_Collecting_and_Analyzing_Data_in_Focus_Group_Research.pdf, accessed 17 March 2018).

10. The global strategy for women's, children's and adolescents' health (2016-2030): survive, strive, transform. New York: United Nations; 2015. (https://sustainabledevelopment.un.org/sdinaction/everywomaneverychild/).

11. "Community engagement is what universities should be for." Times Higher Education, 30 March, 2016 (https://www.timeshighereducation.com/blog/community-engagement-what-universities-should-be\#survey-answer/).

12. Rio political declaration on social determinants of health. Geneva: World Health Organization; 2011 (http://www.who.int/ sdhconference/declaration/en/).

13. Community-based initiatives. Cairo: World Health Organization Regional Office for the Eastern Mediterranean; 2018 (http:// www.emro.who.int/egy/programmes/community-based-initiative.html/, accessed 23 March 2018)

14. de Wit L, Fenenga C, Giammarchi C, di Furia L, Hutter I, de Winter A, et al. Community-based initiatives improving critical health literacy: a systematic review and meta-synthesis of qualitative evidence. BMC Public Health. 2018;18(1):40. http://dx.doi. org/10.1186/s12889-017-4570-7

15. Howland G. Episiotomy, why is this still a thing? Mama Nature; 2018 (https://www.mamanatural.com/episiotomy/, accessed 22 March 2018). 